\title{
The Effect of Foreign Direct Investment on Economic Growth in Ethiopia: A Granger Causality Analysis
}

\author{
Melkamu Wondimu Biru \\ Lecturer, Department of Economics, Mizan- Tepi University, Ethiopia
}

\begin{abstract}
The objective of this study is to investigate the relationship between foreign direct investment and economic growth in Ethiopia by employing an Autoregressive Distributed Lag (ARDL) model. For the purpose of examining the relationship between FDI and economic growth a time series data was collected for the period 1992/93-2018/19. According to the findings of this study, foreign direct investment is found to influence economic growth positively and significantly both in the short run and long run. Moreover, in order to identify the direction of causality between economic growth and foreign direct investment a Granger Causality test were undertaken. The result from the causality test shows that there is a unidirectional causality running from economic growth to FDI. Thus, policies that aim to expand infrastructural facilities and good management skill have to be implemented to attract more foreign direct investment in Ethiopia.
\end{abstract}

Keywords: Economic growth, FDI, ARDL

DOI: $10.7176 /$ RJFA/12-9-013

Publication date:May $31^{\text {st }} 2021$

\section{Introduction}

During the early periods of 1950s and 1960s, foreign direct investment was viewed at with great doubt by some developing countries (DCs). FDI was seen as a dictating factor and transnational corporations (TNCs) were suspected of reducing social welfare by manipulating transfers prices and the formation of economic enclaves. At present there are some witnesses showing a radical change in the attitude of developing countries towards FDI. The behavior of suspicion is now replaced by a promoted attracting policy aiming at substantial inflows of FDI (Oman, 2000). This change in attitude was abundant in part made possible by a global economic environment increasingly liberal and an economic literature highlighting the virtues of FDI. Indeed, several scholars (Dunning, 1993), (Moran, 1998), and (Lall, 2000) granted the important role of FDI to economic development.

Most countries seek to attract foreign direct investment for the reason that it can play an important role in raising a country's technological level, creating new employment, and promoting economic growth. Many countries are therefore actively trying to attract foreign investors in order to promote their economic development (Blomström, 2000).

In this context, since the year 1992 Ethiopia has adopted an approach that makes FDI as the major component of its development plan. Thus, a series of measures have been taken to make the country more attractive to FDI. Following the inflows of FDI in Ethiopia many researchers have tried to investigate the effects of FDI on economic growth and come up with different results.

Admass, (2009) analyzed the impact of foreign direct investment (FDI) and domestic investment (DI) on economic growth in Sub-Saharan Africa for the period 1990-2003 and found positive and significant correlation with Economic growth. The study also found that FDI initially has negative effect on DI and subsequently positive effect in the latter periods for the countries studied. However the researcher fails to give an economic justification for the reason why the effect of FDI was initially negative and later become positive.

Wondoson, (2011) tried to access the impact of FDI on economic growth for the period 1993-2005 and finds a negative association between FDI and economic growth. But this paper has a limitation that there is no appropriate test of stationarity and co-integration taken to avoid statistical problems.

Meskerem, (2014) tried to examine the relationship between economic growth and foreign direct investment in Ethiopia using Ordinary Least Square (OLS) method for the period 1974-2011. Human capital, trade openness, and gross fixed capital formation were employed as additional explanatory variables. The result of the analysis indicated that foreign direct investment has positive and statistically significant impact on growth. However, since she has employed OLS method the direction of causality between the variables of interest is not clearly investigated.

In general, although FDI is influencing the economy of developing countries like Ethiopia very little emphasis were given to explore its direct and indirect effects. However, as stated above these studies have their own knowledge and methodology gaps. So this paper tries to fill these gaps and extend the literature of economic growth and foreign direct investment using available theoretical and empirical data up to 2018/19 in case of Ethiopia. 


\subsection{Objectives of the Study \\ 1.2.1 General Objectives}

The ultimate objective of the study is to examine the relationship between foreign direct investment and economic growth in Ethiopia.

\subsubsection{Specific Objectives}

The specific objectives of the study include the followings:-

$>$ To describe the characteristics of foreign direct investment in relation to economic growth.

$>$ To investigate whether FDI significantly affects economic growth or not.

$>$ To examine the direction of causality between foreign direct investment and economic growth.

\section{Literature Review}

\subsection{Theoretical Literature Review}

\subsubsection{Definition and concepts of economic growth}

Economic growth can be defined as a positive change in the level of goods and services produced by a country over a certain period of time. An important characteristic of economic growth is that it is never uniform or same in all sectors of an economy. Economic growth is measured by the increase in a country's total output or real Gross Domestic Product (GDP) or Gross National Product (GNP). The Gross Domestic Product (GDP) of a country is the total value of all final goods and services produced within a country over a period of time. Therefore an increase in GDP is the increase in a country's production (Agarwal, 2017). Economic growth is influenced by direct factors like quality of human resources, natural resources and the increase in capital employed or technological advancements. It is also influenced by indirect factors such as institutions, the size of the aggregate demand, saving rates and investment rates, the efficiency budgetary and fiscal policies, mobility of labor and capital. There are four main causes of economic growth: human resources, natural resources, capital formation and technology, but the significance that researchers had given each determinant was always different (Teodor \& Constantinescu, 2015)

\subsubsection{Definition and Concepts of Foreign Direct Investment}

Foreign direct investment (FDI) is an investment made by a firm or individual in one country into business interests located in another country. Generally, FDI takes place when an investor establishes foreign business operations or acquires foreign business assets, including establishing ownership or controlling interest in a foreign company. Foreign direct investments are distinguished from portfolio investments in which an investor merely purchases equities of foreign-based companies. Foreign direct investment frequently involves more than just a capital investment. It may include provisions of management or technology as well. The key feature of foreign direct investment is that it establishes either effective control of, or at least substantial influence over, the decision-making of a foreign business (Investopedia, 2018).

\subsubsection{Theoretical foundation behind foreign direct investment}

There are different theories of FDI like; Vernon's Product Life cycle Theory, the Internalization Theory, Neoclassical Theory and the export theory.

Vernon's Product Cycle theory suggests that, firms undertake FDI at particular stages in the life cycle of products they have innovated. It gives more emphasis to invention, the effects of scale economies, and the roles of ignorance and uncertainty in influencing trade patterns. Vernon (1966) cited in (Denisia, 2010) shows that there is an enormous gap between the knowledge of scientific principles and the application of these principles in the generation of new marketable products. The internationalization theory is the other FDI theory which was developed by efforts of Buckley and Casson (1976), Rugman (1981), and Hennart, (1982) cited by (Verbeke, 2007). The theory states that at firm-level multinational corporations will exert proprietary control over an intangible, knowledge-based, and firm-specific advantage which are built based on efficiency. The other prominent theories are the Neoclassical and the export theory of foreign direct investment. The Neoclassical theory states that the future investments flows are directly linked to the package of incentives, which influence the expected rate of return; the security of the investments; the scope and speed with which companies are able to disinvest. The tax regime; investments code or guidelines; and overall macroeconomic policies are all elements affecting FDI (Cockcro \& Ridde, 1991). Export theory on the other hand argues that, countries need to export goods and services in order to generate income to finance imports which cannot be produced domestically. The export theory can be classified under the neoclassical growth models. This theory is the result of a study of Adam Smith (1776), who investigated the nature and causes of wealth of nations.

In general, the theories from the literature review shows the importance of foreign direct investment in influencing the domestic country's economy through technology transfer, skill and knowledge creation, and efficient use of domestic resources resulting in further productivity.

\subsection{Empirical literature}

In the previous sections the theoretical relationship between economic growth and foreign direct investment 
were discussed and, this part deals with the discussion of some of the empirical foundations that suggest how growth and FDI are related to each other.

Using the time series data over the period 1994-2003 (Ek, 2007) analyzed the impact of foreign direct investment on GDP in 30 different regions in China. Based on the empirical results, it was discovered that FDI has no statistically significant impact on growth in China when including the poorest regions in the western area. By using FDI and GDP inflow data series (Mwangi, 2014) explores the impact of foreign direct investment on the Kenyan economy from 2004 to 2013. He used the different types of Statistical Packages, inferential analysis, descriptive analyses, Correlation analysis and trend to establish relationships between the variables and have founded a positive impact of FDI on Kenyan economy.

When we come to the Ethiopian literature there are some works done by the researchers in the area; from among them the most recent one is discussed below to show how economic growth and FDI are correlated.

Using a time series data collected for the period 1974 -2014 (Mulatie, 2017) employed the simultaneous equation econometric model and 3 Stage Least Square estimation technique; and found a positive and statistically significant impact of FDI on economic growth in Ethiopia.

To sum up, as it was shown in the literature, some of the studies which were conducted in Ethiopia shows that foreign direct investment have a positive impact on economic growth. Therefore, relying on the previous studies, this study tries to examine the effect of FDI on economic growth in Ethiopia by identifying the direction of causality between them.

\section{Materials and Methods}

\subsection{Data Type and Data Source}

In order to undertake the study the researcher has relied on secondary data sets which were collected from different sources. The data for real GDP per capital, trade openness, domestic saving rate, and Gross Capital Formation, were collected from National Bank of Ethiopia, whereas the data for foreign direct investment and human capital were obtained from World Bank Development Indicators (WDI) data base.

\subsection{Data Analysis}

After the data was collected from different sources the next step is to analyze the data. In order to analyze the data systematically the researcher has used Eviews 9 software.

\subsection{Specification of the Model}

\subsubsection{The Long Run ARDL Model}

In order to analyze the effects of FDI on economic growth (which is the dependent variable for the study) a linear log-log regression model which shows the linearity between the dependent and independent variables were chosen for this study by relying on the theories from literature review. The base of this model is the Augmented Cobb-Douglas production function applied by (Mwangi, 2014). So, by relying on this, FDI and other explanatory variables are included in the model as the factors determining economic growth. The model takes the form of:Log GDP Growth $=f(\mathrm{HC}, \mathrm{GCF}, \mathrm{FDI}, \mathrm{TO}, \mathrm{NS})$

Where: $\mathrm{HC}=$ Human Capital, $\mathrm{GCF}=$ Gross Capital Formation, FDI= Foreign Direct Investment, $\mathrm{TO}=\mathrm{Trade}$ Openness and NS= National Savings

Mathematically, the long run log-log model which shows the relationship between the dependent and independent variable can be shown by using the following version of ARDL model.

$\operatorname{lnRGDP}{ }_{\mathrm{t}}=\alpha \sum_{i=1}^{n} \alpha_{1} \operatorname{lnRGDP}_{\mathrm{t}-1}+\sum_{i=1}^{k} \alpha_{2} \operatorname{lnHC}_{\mathrm{t}-1}+\sum_{i=1}^{k} \alpha_{3} \operatorname{lnFDI}_{\mathrm{t}-1}+\sum_{i=1}^{k} \alpha_{4} \operatorname{lnTO}_{\mathrm{t}-1}$

$+\sum_{i=1}^{k} \alpha_{5} \operatorname{lnNS}_{\mathrm{t}-1}+\sum_{i=1}^{k} \alpha_{6} \operatorname{lnGCF}_{\mathrm{t}-1}+\mathrm{u}_{\mathrm{t}} \ldots \ldots \ldots \ldots . .(3.1)$

\subsection{Estimation Strategy}

In order to estimate the model the researcher has followed six steps i) the test of stationarity of the individual series in the regression model was undertaken to determine the order of integration of the variables, ii) the ARDL bound Test of Cointegration is undertaken to establish existence of a stable long-run equilibrium relationship among the variables in the model and iii) the estimation of the parameters of the model in equation 3.1 , iv) diagnostic tests were undertaken to ensure that there is no problem in the residuals from the estimation of a model, v) Granger Causality Tests were undertaken to know the direction of causality, and Vi ) Stability tests were undertaken to know whether the parameters in the model are Stability or not.

\section{Results and Discussion \\ 4.1 Descriptive Analysis}

In order to describe the link between the main variables of the study, and observe the characteristics of the variables over time a trend analysis is needed to carry out. 


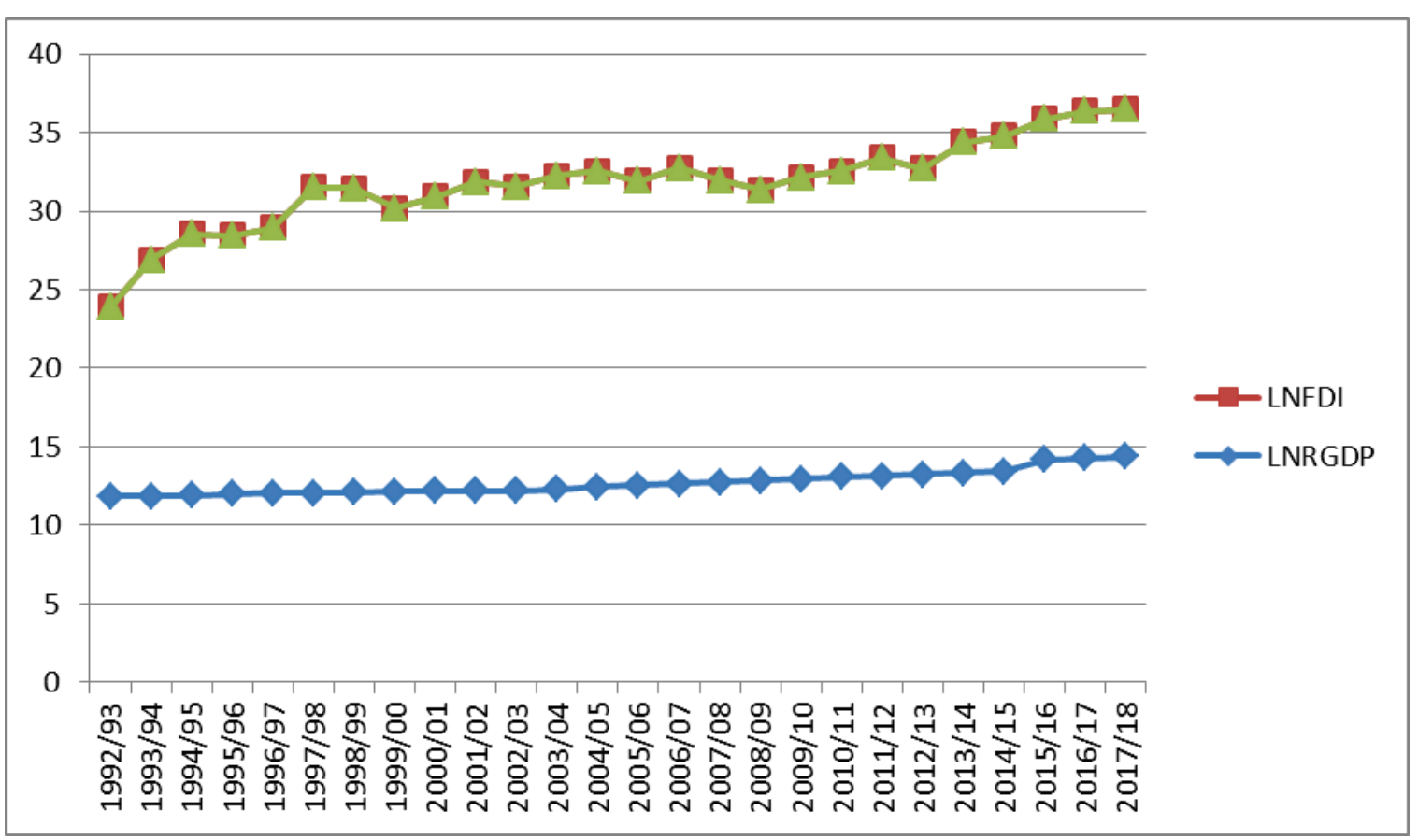

Source: Authors own computation by Microsoft office Excel

Figure $1 \mathrm{~A}$ trend analysis of the relationship between FDI and growth

As it was shown in figure 1, until the year 2004 the trend in growth of real GDP per capital is not fluctuating so much. But after 2005 onwards it starts to increase a bit by bit reaching its peak point in 2018. This increase in Real GDP Per capital is associated with the implementation of growth and transformation plan (GTP II) in Ethiopia. Compared to the growth rate of Real GDP per capital, there is a high fluctuation in FDI inflows in Ethiopia. Starting from the year 1992 the rate of FDI inflows starts to increase slowly reaching the highest point around the year 1999. After 2000 onwards, until the year 2008 where there is a small FDI inflow in Ethiopia, there is a small fluctuation in the rate of FDI inflows. This low rate of FDI inflows in 2008 is associated with the global financial crises which have hindered investment activity resulting in low output growth. After the year 2009 the rate of FDI inflow starts to rise again reaching its boom/peak point in 2018 .

\subsection{Results for stationarity test}

When employing a time series data it is important to undertake a stationarity test, this is because it enables us to avoid the existence of spurious regression in the model. The results for ADF stationary test are shown in table 1.

Table 5 Unit root test

\begin{tabular}{|c|c|c|c|c|c|c|}
\hline \multirow[t]{2}{*}{ Variables } & \multicolumn{3}{|c|}{ ADF t-statistic at level I(0) } & \multicolumn{2}{|c|}{$\begin{array}{l}\text { ADF t-statistic at first difference } \\
\text { I(1) }\end{array}$} & \multirow{2}{*}{ 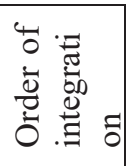 } \\
\hline & Intercept & $\begin{array}{l}\text { Intercept and } \\
\text { trend }\end{array}$ & None & Intercept & $\begin{array}{l}\text { Intercept and } \\
\text { trend }\end{array}$ & \\
\hline lnRGDP & 0.974201 & -1.675251 & $3.301148^{*}$ & $-3.883865^{* * *}$ & $-4.292849 *$ & $\mathrm{I}(1)$ \\
\hline $\ln \mathrm{HC}$ & -1.148685 & -2.555608 & 1.364776 & $-9.417479 *$ & $-4.258294 * *$ & $\mathrm{I}(1)$ \\
\hline $\operatorname{lnFDI}$ & $-8.146303 *$ & -2.866327 & 0.613227 & $-4.959993 *$ & $-4.766522 *$ & $\mathrm{I}(0)$ \\
\hline $\ln \mathrm{TO}$ & $-3.355176^{* *}$ & -2.660920 & $-2.868928^{*}$ & -0.941526 & 0.859917 & $\mathrm{I}(0)$ \\
\hline $\operatorname{lnNS}$ & 2.270050 & -0.674852 & 4.697563* & $-3.737222 * *$ & $-5.027056^{*}$ & $\mathrm{I}(1)$ \\
\hline $\operatorname{lnGCF}$ & 2.642224 & -0.815056 & $3.427785^{*}$ & $-4.175720^{*}$ & $-3.787901 * * *$ & $\mathrm{I}(1)$ \\
\hline
\end{tabular}

Source: Authors own computation by Eviews 9

Mackinnon (1996) Critical Values

Critical Values Intercept Intercept \& trend None Significance

$\begin{array}{lllll}1 \% & -3.886751 & -4.616209 & -2.708094 & * \\ 5 \% & -3.052169 & -3.710482 & -1.962813 & * * \\ 10 \% & -2.666593 & -3.297799 & -1.606129 & * *\end{array}$

Note: $*, * *, * *$ shows that the variables are significant at $1 \%, 5 \%$ and $10 \%$ respectively.

As it was shown in table 1 out of the six variables for which the stationarity test were undertaken four of them, namely $\operatorname{lnRGDP}, \operatorname{lnHC}, \operatorname{lnNS}$ and $\operatorname{lnGCF}$ are stationary after first difference. On the other hand the stationarity test for the remaining two variables, $\operatorname{lnFDI}$ and $\operatorname{lnTO}$ shows that the variables are stationary at level. Since all of the variables included in the model are stationary at $\mathrm{I}(\mathrm{O})$ and $\mathrm{I}(1)$ it is possible to apply ARDL model. 


\subsection{Results for Bound Test of Cointegration}

In order to ensure the existence of the causality among the underlying variables in ARDL model, it is mandatory to undertake the Bounds Test for Cointegration. This test was developed by Pesaran et al. (2001) and can be applied for variables with order of integration of I(0), I(1) or mutually exclusive.

Table 2 ARDL Bound Approach to Cointegration

\begin{tabular}{|l|l|l|l|l|}
\hline \multicolumn{2}{|c|}{} & $\begin{array}{l}\text { Critical value bounds based on Pasaran et.al values } \\
\text { of 2001 }\end{array}$ \\
\hline Test statistic & Value & level of Statistical significance & $\mathrm{I}(0)$ & $\mathrm{I}(1)$ \\
\hline \multirow{3}{*}{ F- statistic } & \multirow{2}{*}{4.43} & $1 \%$ & 2.08 & 3 \\
\cline { 3 - 5 } & & $5 \%$ & 2.39 & 3.38 \\
\cline { 2 - 5 } & $10 \%$ & 2.7 & 3.73 \\
\hline
\end{tabular}

Source: Authors own computation by Eviews 9

According to the results from bound test of cointegration represented in table 2, since the Pasarian Fstatistic critical values of 4.43 are greater than the Pasarian upper bound critical values I(1) of (3) at 1\%, the null hypothesis of no cointegration is rejected, and the existence of the long run relationship between the variables is guaranteed.

\subsection{Estimation Results of the Long run ARDL model}

After the existence of the long run relationship between the variables is determined, the next issue is estimation of the long run coefficients of the ARDL model. In any of the regression analysis the values of unknown dependent variable is predicted based on the known values of the independent variables.

The long run ARDL model equation can be written as follows:

$\operatorname{lnRGDP}=9.33+0.36 \ln \mathrm{HC}+0.04 \operatorname{lnFDI}+0.000447 \operatorname{lnTO}+0.000003 \ln \mathrm{NS}-0.22 \ln \mathrm{GCF}$

Table 3 Coefficients of the Long Run Model

\begin{tabular}{|l|ll|l|l|}
\hline Variables & Coefficient & Std. Error & T-Ratio [Prob.] \\
\hline $\ln \mathrm{HC}$ & 0.366857 & 0.146901 & $2.497315\left[0.0412^{*}\right]$ \\
\hline $\ln \mathrm{FDI}$ & 0.042997 & 0.018105 & $2.374879[0.0493 *]$ \\
\hline $\ln \mathrm{TO}$ & 0.000447 & 0.000556 & $0.805428[0.4471]$ \\
\hline $\ln \mathrm{NS}$ & 0.000003 & 0.000001 & $2.577137\left[0.0366^{*}\right]$ \\
\hline $\ln \mathrm{GCF}$ & -0.222819 & & 0.376779 & $-0.591377[0.5729]$ \\
\hline $\mathrm{C}$ & 9.330938 & 3.003076 & $3.107127[0.0172 *]$ \\
\hline R-squared & 0.999427 & Mean dependent var & 13.05648 \\
Adjusted R-squared & 0.998690 & S.D. dependent var & 0.696721 \\
S.E. of regression & 0.025219 & Akaike info criterion & -4.233258 \\
Sum squared resid & 0.004452 & Schwarz criterion & -3.743132 \\
Log likelihood & 45.98269 & Hannan-Quinn criter. & -4.184539 \\
F-statistic & 1356.079 & Durbin-Watson stat & 2.363358 \\
Prob(F-statistic) & 0.000000 &
\end{tabular}

Authors own computation by Eviews 9

Note: *, shows that the probability values of the coefficients in the parentheses are significant at 5 percent.

As it was shown in table 3, the R-squared of the model tells us that $99 \%$ of the variation in real GDP which is the dependent variable is explained by all the independent variables included in the model. In addition to the R-squared value, since the F-statistic probability value is very significant the model is precise.

As it was expected human capital development proxied by secondary school enrollment is found to influence economic growth positively. A one percent increase in human capital will result in 36.66 percent increase in GDP holding other factors constant. This is similar to the findings of (Hassen \& Anis, 2012), were the domestic educational policies contribute to an improvement in skill and know-how to reduce the spillover effects of FDI.

Foreign direct investment which is a central variable for the study is found to influence economic growth positively. Holding other factors constant, a one percent increase in foreign direct investment will result in 4.29 percent increase in the growth of an economy. There are also other empirical studies which show a positive relationship between FDI and growth. For instance, (Ilhan, 2007) Conducted over 50 empirical investigations on the relationship between FDI and economic growth, and 40 of such studies have showed a positive correlation with only 2 reporting negative and the rest indicating no effect. These empirical findings show that most FDIs result in growth of an economy. Furthermore, a study conducted by (Sokang, 2018) in Cambodia also reveals a positive impact of FDI on growth.

National saving is also found to affect economic growth positively. A one percent increase in national saving affects the growth of an output by 0.0003 percent holding the other factors constant. The findings of the 
study undertaken by (Tang \& Chau, 2009) on the relationship between savings and growth in Malaysia by using non-parametric cointegration test and DOLS method have also found a positive impact of saving on economic growth

The other explanatory variable incorporated in the model for this study is gross capital formation. Unexpectedly this variable is found to influence economic growth negatively. A one percent increase in the physical capital stock will result in 22.28 percent decrease in the growth of an economy. This may be due to the reason that in most developing countries like Ethiopia, the maximum saving requirements to bring the targeted real GDP growth is less than the minimum saving requirement to bring the targeted growth of an economy, resulting in saving gap or saving investment gap.

\subsection{Estimation Results of the Short Run and Error Correction Model}

Once the long run model is clearly specified and the effect of the independent variables on the dependent variable is clearly interpreted, the next task is the estimation of the short run coefficients along with the short run Error Correction Term (ECT). Thus the ECT shows the short run dynamics of the model beside with the long run adjustment.

In order to confirm an adjustment towards the long run equilibrium the lagged values of ECT has to be negative and statistically significant. As it was shown in table 4, the lagged value of the ECT is negative and statistically significant. The magnitude of the error correction term in this model is about -0.410768 and this shows that about $41.07 \%$ of the deviation from the long run equilibrium is corrected during each year.

Table 4 Estimates of the short run and Error Correction Term (ECT)

\begin{tabular}{|l|l|l|l|}
\hline Variable & Coefficient & Std. Error & T-Ratio [Prob.] \\
\hline D(LNHC) & 0.082823 & 0.028998 & $2.856186[0.0245]^{*}$ \\
\hline D(LNGCF) & 0.158724 & 0.113470 & $1.398822[0.2046]$ \\
\hline D(LNFDI) & 0.017662 & 0.007292 & $2.422017[0.0460]^{*}$ \\
\hline D(LNTO) & -0.000618 & 0.000208 & $-2.965858[0.0209]^{*}$ \\
\hline D(LNNS) & 0.000001 & 0.000000 & $3.446486[0.0107]^{*}$ \\
\hline ETC(-1) & -0.410768 & 0.117971 & $-3.481941[0.0102]^{*}$ \\
\hline
\end{tabular}

Authors own computation by Eviews 9

Note: *, shows that the probability values of the coefficients in the parentheses are significant at 5 percent.

Besides the long run model, in the short run human capital is found to have a positive and statistically significant impact on Ethiopian economy. A one percent increase in secondary school enrollment rate will lead to 8.28 percent increase in real GDP per capital, holding other factors constant.

Foreign direct investment is also found to influence economic growth both positively and significantly in the short run. When FDI inflow increases by one percent; the economic growth rate increases by 1.76 percent.

Similar to the long run model estimation result, the short run model result shows, the positive and significant effect of national saving on the growth of real GDP per capital. Holding other factors constant, when the domestic saving rate increases by one percent the economic growth rate increases by 0.0001 percent.

In the short run, trade openness is found to have a negative and statistically significant effect on the economy. When the degree of openness to an economy increases by one percent; the real GDP per capital growth rate decreases by 0.06 percent. This negative effect of openness on an economy is the result of Ethiopian trade structure, which is characterized by prolonged deficit.

\subsection{Model Diagnostic Tests}

Once the long run and the short run coefficients are estimated the next most important step in any model is to undertake the model diagnostic tests on the estimates of the residual of the ECM model. Diagnostic checks are crucial in this analysis, because if there is a problem in the residuals from the estimation of a model, it is an indication that the model is not efficient, such that parameter estimates from such model may be biased. Results from various tests such as the Jarque- Bera normality test, Breusch Pagan Godfrey serial correlation LM test, the Breusch Pagan Godfrey heteroskedasticity and Ramsey RESET model specification tests undertaken in this study are presented in table 5 .

Table 5 Diagnostic Tests

\begin{tabular}{|l|l|l|}
\hline Types of tests & $\mathrm{LM}-$ Version & $\mathrm{F}-$ Version \\
\hline Serial Correlation & $\mathrm{CHSQ}(2)=2.576180[0.2758]$ & $\mathrm{F}(2,5)=0.446515[0.6631]$ \\
\hline Normality & $3.814854[0.148462]$ & Not applicable \\
\hline Hetroscedasticity $(\mathrm{BPG})$ & $\mathrm{CHSQ}(9)=5.839903[0.7558]$ & $\mathrm{F}(9,7)=0.406999[0.8953]$ \\
\hline Ramsey RESET test & $\mathrm{df}(6) 1.009890[0.3515]$ & $\mathrm{df}(1,6)=1.019878[0.3515]$ \\
\hline
\end{tabular}

Source: Authors own computation

The results from the analysis show that the residual from the error correction model is normally distributed 
because the P-value of the series, which is represented in our case as figures in parentheses, was insignificant. The null hypothesis of no serial correlation as confirmed by Serial Correlation LM Test cannot be rejected since the test statistics are also not significant. The test also confirms the absence of heteroskedasticity using the Breusch Pagan-Godfrey (BPG) heteroskedasticity test. The Ramsey RESET test also indicates that there is no specification error in the model, hence indicating that the model is well behaved.

\subsection{A Granger Causality test}

For the purpose of determining the direction of causality between FDI and economic growth a Granger causality test were undertaken and the results from the model shows that there is a unidirectional causality running from economic growth to foreign direct investment.

Table 6 A Granger Causality test

\begin{tabular}{|l|l|l|l|}
\hline Null hypothesis & Obs & F-Statistic & Prob. \\
\hline LNFDI does not Granger Cause LNRGDP & 25 & 0.53338 & 0.4729 \\
\cline { 1 - 1 } LNRGDP does not Granger Cause LNFDI & & 6.75800 & 0.0164 \\
\hline
\end{tabular}

Since we fail to reject the null hypothesis of LNFDI does not Granger Cause LNRGDP and able to reject the null hypothesis of LNRGDP does not Granger Cause LNFDI at 5\% level of significance, we can conclude that economic growth is causing more FDI to inflow in Ethiopia. The findings from this study is similar to that of (Shettima \& Saleh, 2017), whose study indicates only a one-way causality, running from economic growth (measured by GDP at current basic price) to FDI in Nigeria. Therefore, by utilizing the national resource base, the economy of Ethiopia should grow fast to create a conducive environment for more FDI inflows.

\subsection{Stability Test}

In addition to the diagnostic tests, in order to guarantee the goodness of the model cumulative sum (CUSUM) and CUSUM of squares tests of structural break for the long run relationship equation were conducted and we found that there were no structural breaks as it was seen in the model. Since the cumulative sum and the cumulative sum of squares of the residual lies in between the two critical lines as it was shown in figure 2 and figure 3 respectively, the parameters are stable.

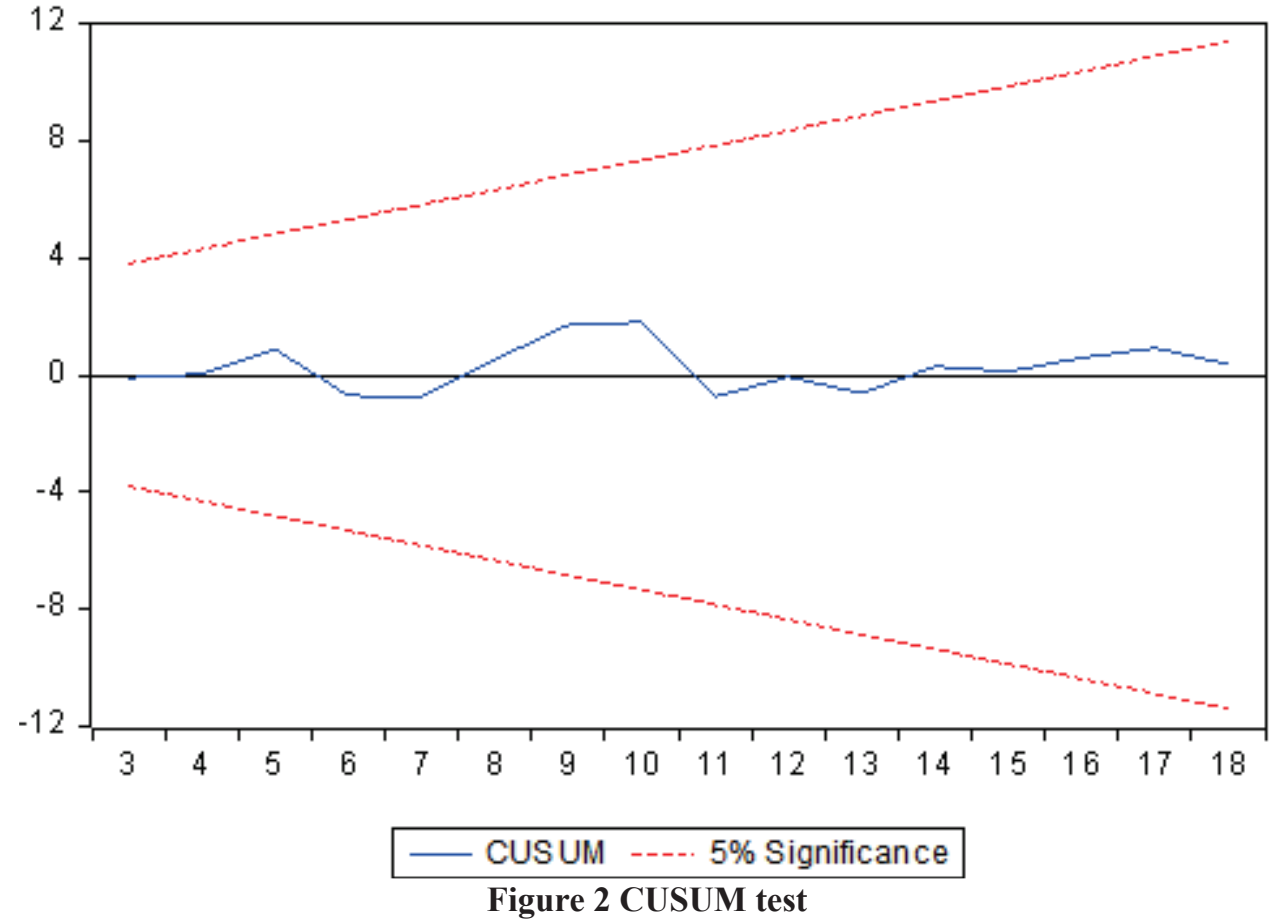




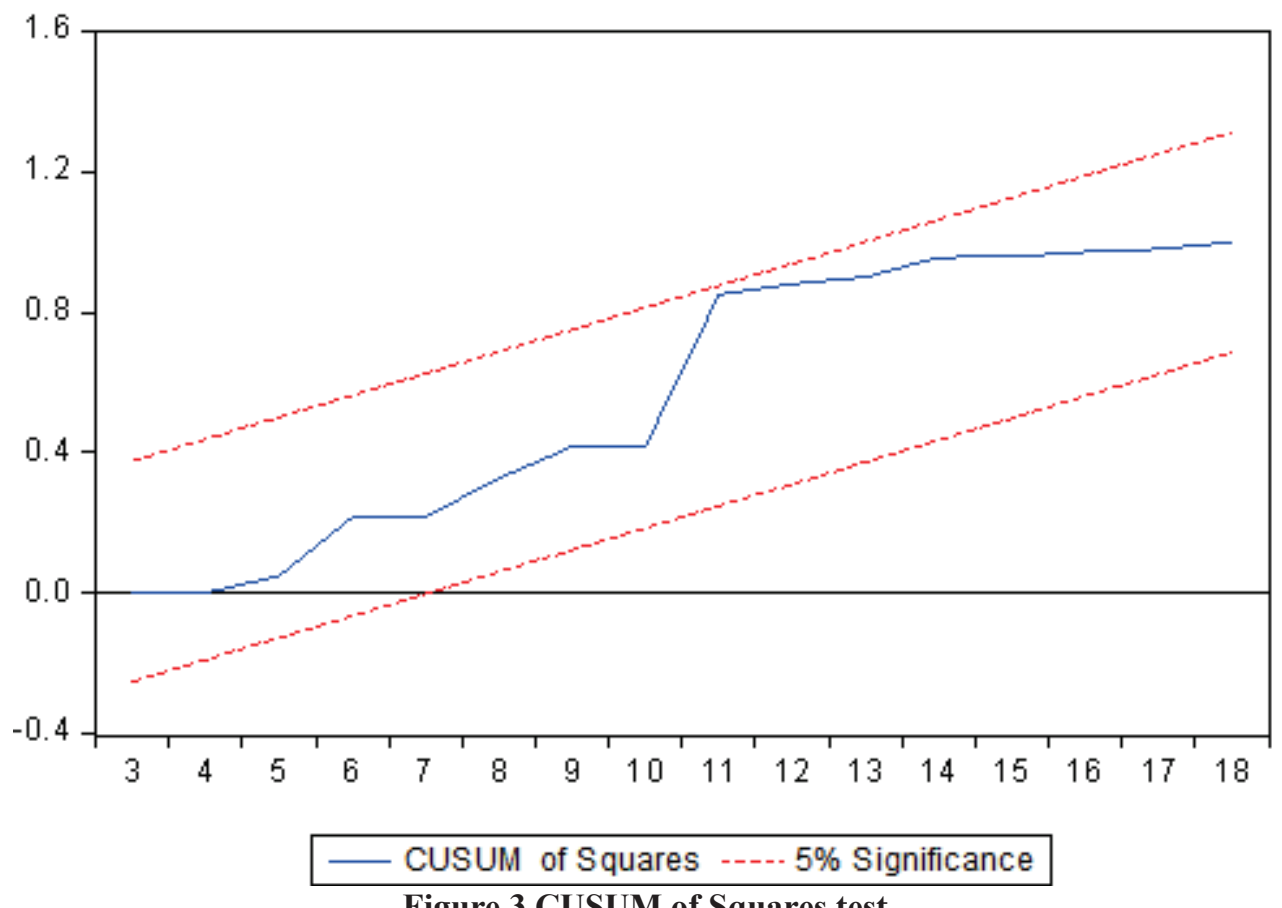

Figure 3 CUSUM of Squares test

\section{Conclusion and Policy Recommendations}

This study was conducted to investigate the effect of foreign direct investment on economic growth in Ethiopia by employing ARDL model. For the purpose of examining the relationship between FDI and economic growth; a time series data for macro-economic variables like gross capital formation, national saving, human capital, FDI, Real GDP per capital and trade openness were collected for the period 1992/93-2018/19. Moreover in order to identify the direction of causality between economic growth and foreign direct investment a Granger Causality test is undertaken. The results from the causality test show that there is a unidirectional causality running from economic growth to FDI.

The results from the study convey that human capital measured by secondary school enrollment rate, foreign direct investment inflows and the domestic saving rate measured in terms of Monetary value was found to influence the economic growth of Ethiopia positively and significantly both in the short run and long run. Trade openness which is included in the model as the natural logarithm of the ratio of import plus export to GDP is found to influence the economic growth of Ethiopia negatively and significantly in the short run. In general, the effect of FDI on economic growth depends on local socioeconomic conditions such as the quality of institutions, and development plans which are sector, scope and time specific.

Thus, Policies that aim to increase the degree of trade openness, level of domestic saving rate, investment on both human and physical capital should have to be implemented to increase the benefit from FDI inflows.

\section{References}

Admass. (2009). Effect of Foreign Direct Investment On Economic Growth.

Agarwal, p. (2017, December 26). Retrieved from https:// www.intelligent economist.com/ author/ prateek Agarwal/.

Blomström,M.(2000). The Economics of International Investment Incentives. Interntaional Investment Perspectives, pp. 165-183.

Chukwuka, I., \& Stella, E. (2012). Economic Growth and Foreign Direct Investment in Nigeria: An Empirical Investigation.

Cockcro, L., \& Ridde, R. C. (1991). Foreign Direct Investment in Sub-Saharan Africa .

Denisia, V. (2010). Foreign Direct Investment Theories: An Overview of the Main FDI Theories. Academy of Economic Studies.

Ek, A. (2007). The Impact of FDI on Economic Growth The Case of China.

Hassen, S., \& Anis, O. (2012). Foreign Direct Investment (FDI) and Economic Growth: an approach in terms of cointegration for the case of Tunisia. Journal of Applied Finance \& Banking, vol.2, no.4, 2012, 193-207, 194-207.

Ilhan, O. (2007). Foreign Direct Investment - Growth Nexus: A Review of the recent literature. International Journal of Applied Econometrics and Quantitative Studies, PP- 79-98. 
Investopedia. (2018). Foreign Direct Investment - FDI.

Lall, S. (2000). FDI and Development: Policy and Research Issues in the Emerging Context. Queen Elizabeth House, University of Oxford.

Meskerem, D. (2014). Impact of Foreign Direct Investment on Economic growth of Ethiopia.

Moran, T. H. (1998). Foreign Direct Investment and Development. Institute For International Economics.

Mulatie, C. (2017). The Effect Of Foreign Direct Investment On Economic Growth In Ethiopia;An Empirical Investigation. International Journal Of Current Research.

Mwangi, K. (2014). The Effect Of Foreign Direct Investments On Economic Growth In Kenya.

Oman, C.(2000). Policy Competition for Foreign Direct Investment. Journal Of Development Studies.

Pesaran M. H. Shin, Y. and Smith R. J. (2001). Bounds Testing Approaches to the Analysis of Level Relationships. Journal of Applied Econometrics, 16(February 1999), 289-326.

Shettima, M., \& Saleh, M. (2017). Foreign Direct Investment And Economic Growth: A Test of Granger Causality in Nigeria. African Journal of Research and Sustainable Development.

Sokang, K. (2018). The Impact of Foreign Direct Investment on the Economic Growth in Cambodia: Empirical Evidence. International Journal of Innovation and Economic Development, PP 31-38.

Tang, C. F., \& Chau, S. Y. (2009). The savings-growth nexus in Malaysia: Evidence from nonparametric analysis. The IUP Journal of Financial Economics, PP 83-94.

Teodor, F., \& Constantinescu, L. (2015). The main determinants affecting economic growth. Braşov: Transilvania University

Verbeke, A. M. (2007). Internalization Theory and its Impact on the Field of International Business.

Wondoson. (2011). Impact of Foreign Direct Investment On Economic Growth. 